\title{
STUDIES ON FUZZY LOGIC CONTROL OF ELECTRICAL MACHINES IN TURKISH UNIVERSITIES: AN OVERVIEW
}

\author{
Aykut Kentli \\ Department of Mechanical Engineering \\ Marmara University, 34722 \\ Kadıköy, Istanbul, Turkey \\ akentli@marmara.edu.tr
}

\begin{abstract}
This study mainly surveys the $\mathrm{PhD}$ and Master Theses on fuzzy logic control in Turkey. It is beneficial for researchers to know the previous studies on their subject, in an organized way. From this point of view, it is expected that this study will help the researchers on fuzzy logic control as there is no similar study on this area. In this study, background information on fuzzy logic is given, and applications on electrical machines are summarized and compared. Lastly, future recommendations are given for new researchers.
\end{abstract}

Key Words- Fuzzy Logic, Electrical Machines, Control

\section{INTRODUCTION}

Pioneering study on fuzzy logic is done by Lotfi Zadeh in 1965[1]. First working group on fuzzy systems is established in Japan by Toshiro Terano in 1972. Zadeh (USA) published paper about fuzzy algorithm in 1973[2]. First fuzzy logic control application, control of steam engine, is implemented by Ebrahim Mamdani (UK) in 1974 [3]. First fuzzy expert system for loan applicant evaluation is prepared by Hans Zimmermann (Germany) in 1977. Cement kiln control is accomplished by F.-L. Smidth \& Co.-Lauritz P. Holmblad (Denmark) in 1980 [4]. Subway Sendai Transportation System (Japan) control is done by fuzzy logic in 1984. First fuzzy chip is developed by Masaki Togai and Hiroyuke Watanabe in Bell Labs (USA) in 1985. Laboratory for International Fuzzy Engineering Research (LIFE) is created in Japan in 1989.Fuzzy Logic Systems Institute (FLSI) by Takeshi Yamakawa (Japan) and Intelligent Systems Control Laboratory in Siemens (Germany) is established in 1990 [5]. After a while, due to the easiness and variety of fuzzy logic control applications, studies on this area are quickly spread out. There are too many studies, inventions and projects to mention. In this duration, fuzzy logic has been used on many areas: especially on decision making, optimization and classification areas.

Today, fuzzy logic hasn't lost its value yet. Each year, thousands of studies are carried out on this field over the world. Turkey also produces its share from these studies. But, there are few or no studies on some areas while studies on the other areas have been increasing because variety of the studies' contents and application areas were not investigated. This study investigates one of the application areas of fuzzy logic to fill this gap.

Scope of this study is narrowed to be able to investigate thoroughly due to extensiveness of the application area. Only the studies on fuzzy logic control of 
electrical machines are investigated. In this study, firstly, background information on fuzzy logic and electrical machines are given. Then, studies in Turkish universities are summarized and compared. Lastly, recommendations for future studies are given.

\section{FUZZY LOGIC}

Over the past few decades, the use of fuzzy set theory, or fuzzy logic, in control systems has gained widespread popularity, especially in Japan. From as early as the mid-1970s, Japanese scientists have been instrumental in transforming the theory of fuzzy logic into a technological realization. Today, fuzzy logic-based control systems, or simply fuzzy logic controllers (FLCs), can be found in a growing number of products, from washing machines to speedboats, from air condition units to handheld auto focus cameras.

The inference engine is the heart of a fuzzy controller (and any fuzzy rules system) operation. Its actual operation can be divided into three steps (Figure 1):

i) Fuzzification - actual inputs are fuzzified and fuzzy inputs are obtained. ii) Fuzzy processing - processing fuzzy inputs according to the rules set and producing fuzzy outputs. iii) Defuzzification - producing a crisp real value for a fuzzy output.

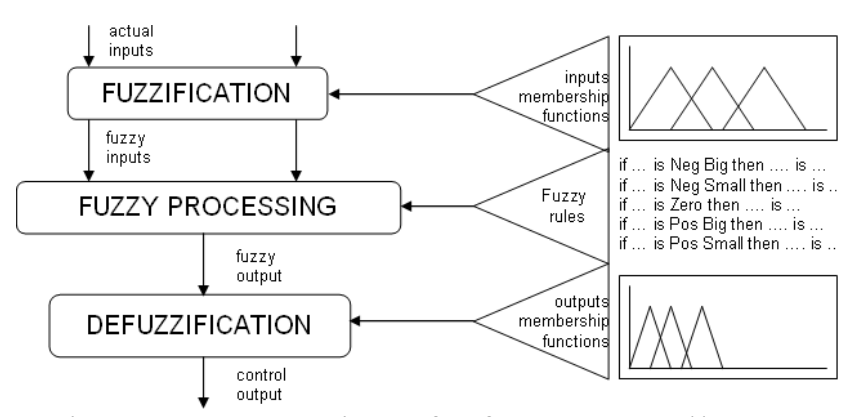

Figure 1 - Operation of a fuzzy controller [5].

\section{CLASSIFICATION OF ELECTRICAL MACHINES}

Electrical machines can be classified into the different groups from different perspectives. From their function perspective, they could be classified into three groups: Transformers, Motors and Generators. From current perspective, they could be classified into two groups: DC machines and AC machines. From working principle perspective, they could be classified into four groups: Fixed (Stationary) type, Rotating type, Traveling (Linear) type and Special purpose machines. Summarized explanations on all type machines will be given at the following paragraphs.

\subsection{From Function Perspective}

It is possible to classify electrical machines in terms of their energy conversion characteristics. Transformers only can step an AC voltage up or down by a fixed ratio, with a corresponding decrease or increase in current (keep frequency and power constant). Transformers do not convert the energy into another form. On the other hand, a machine acts as a generator if it converts mechanical energy from a prime mover to electrical form. A machine is classified as a motor if it converts electrical energy to 
mechanical form. The latter class of machines is probably of more direct interest to researchers, because of its widespread application in engineering practice [6].

\subsection{From Current Perspective}

Electrical machines are broadly classified into DC and AC machines; the former use DC excitation for both the pole field and armature circuits, while the latter may be further subdivided into two classes: synchronous machines, and induction motors. AC synchronous machines are characterized by $\mathrm{DC}$ field for poles and $\mathrm{AC}$ armature excitation. Induction motors, on the other hand, do not require a field excitation, since this is provided by electromagnetic induction. Typically, DC machines have the armature winding on the rotor, while AC machines have it on the stator or armature. Slip-ring asynchronous machines have also winding on the rotor.

\subsubsection{Current}

Five basic types of DC machines are commonly used. Their principal operating characteristics are summarized as follows.

Separately-excited DC machine: The field winding is connected to a separate Dc supply. Speed and torque can be easily controlled for motors while voltage can be easily controlled for generators.

Shunt DC machine: Field (pole) winding is connected in parallel with the armature winding. With constant armature voltage and field excitation, in motor mode, the motor has good speed regulation (flat speed-load characteristic).

Compound DC machine: Field winding has both series and shunt components. This type of machine can be classified into the four groups: over compounded, flat compounded (constant voltage), under compounded and differentially compounded. They are named according to if the series winding field fortifies the shunt winding field or not. In motor mode, this motor offers better starting torque than the shunt motor, if the series winding field is added to shunt winding field, but worse speed regulation.

Series DC machine: The field winding is in series with the armature winding. In motor mode, the motor has very high starting torque and poor speed regulation. It is useful for low-speed, high-torque and large starting current applications.

Permanent-Magnet (PM) DC machine: Field windings are replaced by permanent magnets. In motor mode, the motor has adequate starting torque and its torque is proportional to armature current, with speed regulation somewhat worse than that of the flat compounded wound motor. In generator mode, the armature voltage is proportional to the speed.

\subsubsection{AC Current}

In fact, the AC induction motor is the workhorse of many industrial applications, and synchronous generators are used almost exclusively for the generation of electric power worldwide. The structure of the windings is the same whether the AC machine is a motor or a generator; the distinction between the two depends on the direction of power flow.

One of the most common AC machines is the synchronous generator, or alternator. Alternators are classified into two groups according to the construction of armature: rotating armature and stationary armature. The most widely used type is the 
stationary armature type. In stationary armature type, the field winding is on the rotor, and the excitation current connection is made by means of brushes. The rotor field is obtained by means of a DC current provided to the rotor winding, or by permanent magnets. The rotating armature type is in an arrangement similar to that of the DC machines. In this type, the field winding is on the stator, and the load current is made by means of brushes.

\subsection{From Working Principle Perspective}

\subsubsection{Fixed (Stationary) Type Electrical Machines}

Transformer is mostly known fixed type electrical machine. A transformer is an electromagnetic device having two or more stationary coils coupled through a mutual flux. A two-winding ideal transformer is assumed to have (i) an infinitely permeable core with no losses (ii) lossless electrical winding and (iii) no leakage fluxes.

\subsubsection{Rotating Type Electrical Machines}

This type of machines has two main components: rotor and stator. A stator, of cylindrical shape, and a rotor, which, as the name indicates, rotates inside the stator, separated from the latter by means of an air gap. The rotor and stator each consist of a magnetic core, some electrical insulation, and the windings necessary to establish a magnetic flux (unless this is created by a permanent magnet).

An immediate distinction can be made between different types of windings characterized by the nature of the current they carry. In DC machines and AC synchronous machines, separate windings exist to carry field and armature currents. In the induction motor, the magnetizing and load currents flow in the same winding.

\subsubsection{Traveling (Linear) Type Electrical Machines}

The majority of electrical machines are designed to produce rotary motion. Electromagnetic forces may also be employed to produce linear motion resulting in linear motion electrical machines (LEMs). In principle, there is a LEM counterpart of every rotary motion electrical machine. However, for potential applications only the linear induction machines (LIMs) and the linear synchronous machines (LSMs) which are the respective counterparts of rotating induction and synchronous machines, are considered to be economically feasible. Furthermore only linear motors, rather than generators, have found applications so far. But, DC linear machines are not very common.

Because the topology of the magnetic circuit of a LEM can be varied easily, there are many more diverse types of LIMs and LSMs than rotating induction and synchronous motors. Thus, the LIMs and LSMs are classified from topological (electrical, magnetic, mechanical and geometric) considerations in addition to the classification in rotating machines [7].

\subsubsection{Special-Purpose Electrical Machines}

The most common engineering applications of electric machines make use of a number of special-purpose motors. Common special-purpose electric machines are 
brushless DC motors, stepper motors, switched reluctance motors, universal motors and single-phase induction motors.

The brushless DC motor is a PM synchronous motor in which the mechanical commutation of conventional DC motors is replaced by electronic commutation. Stepping motors of the variable-reluctance, PM, or hybrid type permit fine angular displacement control by moving in fixed, discrete steps.

The universal motor is very similar in construction to a series DC motor but can operate on both DC and AC supplies; its speed can be controlled by means of electronic circuitry of modest complexity.

Squirrel-cage induction motors can be operated on a single-phase AC supply if a means is provided for establishing a starting torque. Various techniques are commonly employed, such as split-phase, capacitor-start, and shaded-pole construction [8].

\section{CONTROL OF ELECTRICAL MACHINES}

Electric motors are major users of electricity in industrial plants and commercial premises. Previously, DC motors were extensively used in complex speed and position control applications, such as industrial robots and numerically controlled machinery, because their flux and torque can be easily controlled. However, DC motors have the disadvantage of using a commutator, which increases the motor size, the maintenance cost and reduces the motor life. Advances in digital technology and power electronics have made the induction motor control a cost-effective solution. Therefore, DC motors are currently being replaced by induction motors in many industrial plants.

The speed and/or position sensors ensure high operation accuracy for the closedloop systems. In some practical situations, however, there are strong reasons to eliminate the speed sensor due to both economical and technical reasons. Recently, it has been shown that speed can be calculated from the current and voltage across the AC motor thereby eliminating the need for speed sensors. There have been many alternative proposals addressing the problem of speed sensorless induction motor control. These methods are mathematically intensive as they imply the online calculation of the spacevector motor model [9]. Figure 2 shows the main control techniques.

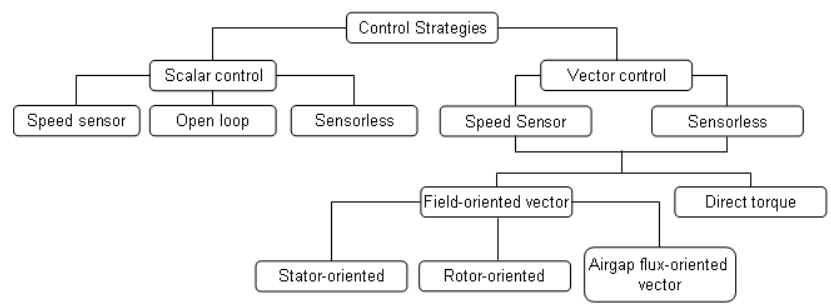

Figure 2 - Classification of control strategies.

\section{FUZZY LOGIC CONTROL OF ELECTRICAL MACHINES}

Over the past two decades, there has been a tremendous growth in the use of fuzzy logic controllers in power systems as well as power electronic applications. A series of tutorials [10], [11] which focused entirely on the applications of fuzzy logic in power systems is evidence of its growing significance in the field. 
The success of fuzzy logic controllers is mainly due to their ability to cope with knowledge represented in a linguistic form instead of representation in the conventional mathematical framework. Control engineers have traditionally relied on mathematical models for their designs. However, the more complex a system, the less effective the mathematical model. The advantages of using fuzzy logic include the following [9]:

i) Fuzzy controllers are more robust than PID controllers because they can cover a much wider range of operating conditions than PID can, and can operate with noise and disturbances of different natures. ii) Developing a fuzzy controller is cheaper than developing a model-based or other controller to do the same thing. iii) Fuzzy controllers are customizable, since it is easier to understand and modify their rules, which not only use a human operator's strategy but also are expressed in natural linguistic terms. iv) It is easy to learn how fuzzy controllers operate, and how to design and apply them to a concrete application.

\section{STUDIES ON FUZZY LOGIC CONTROL OF ELECTRICAL MACHINES}

This work has aimed to reveal the extent of studies in Turkish Universities done on fuzzy logic control of electrical machines. Scope of the study is limited to MSc and $\mathrm{PhD}$ theses. A brief classification and explanation on fuzzy logic control and electrical machines has already given above. At the following paragraphs, studies are summarized in this context [12-73].

\subsection{Fixed Type Electric Machines}

There is no work on this area.

\subsection{Rotating Type Electric Machines}

Much of the studies cover this topic. Few of them are on generators. Rest of them is on motors.

\subsubsection{Generators}

Kavruk [12] has used fuzzy logic with neural network. Hydro-turbine speed control was achieved for hydroelectric power plant (using a synchronous generator) by using neuro-fuzzy control method. Kinalı [13] has applied it to the regenerative energy systems. In his study, fuzzy gain scheduled PI (fuzzy PI) controller is compared with PI controller in order to control a wind turbine and an asynchronous generator attached to it for controlling the power and enthalpy output of a thermal electrical power plant. Oğuz [14] and Eker [15] have worked on control of the excitation circuit of the synchronous generator using fuzzy logic. Caner [16] has studied on dynamic performance of excitation control system that is an important component for power generation. Hierarchical fuzzy control method which has not been previously applied in excitation control systems is used as a novel control method.

\subsubsection{Motors}

Studies will be divided into two parts, AC and DC motors.

AC motors: Çaşkurlu [17] has controlled three-phase asynchronous motor. Uygur [18] has implemented speed control system of an asynchronous motor by using neuro-fuzzy 
methods. He used an inverter as a drive to scalar control. Demirtaş [19] has worked on fuzzy sliding mode control and genetic sliding mode control for position of vector controlled induction motors. Arınç [20] used the fuzzy logic method with speed control of induction motor and simulation. Dandil [21] managed robust speed control of induction motor using neuro-fuzzy controller. Bal [22] worked on sensorless speed control of induction motor using sliding mode and neuro-fuzzy observers. Y1ldiz [23] used a Model Reference Adaptive Control (MRAC) scheme based on Genetic Algorithm (GA) and Fuzzy Logic (FL) by the help of Vector Control type driving method based on Space Vector Pulse Width Modulation (SVPWM) to control a squirrel-cage induction motor. Kıvanç [24] applied adaptive fuzzy controller of a thermal system and an induction motor using existing PLCs. Gümüş [25] managed vector control of permanent magnet synchronous motor with using fuzzy logic observer. Üstün [26] managed speed control of the permanent magnet synchronous motor using parallel associated fuzzy neural and sliding mode controllers. Kaytez [27] worked on synchronous electrical machine control by classical PID and fuzzy logic controller. Teker [28] managed the speed control of permanent magnet synchronous motor (p.m.s.m.) by fuzzy logic. Kılıç [29] worked on control of power coefficient of a synchronous motor.

DC motors: Faris [30] designed low cost yet effective fuzzy controller for speed control of a DC motor. Two methods PI and fuzzy logic were compared. Baysal [31] controlled the speed of a DC motor was controlled using an adaptive neuro-fuzzy inference system (ANFIS). The system was primarily simulated in Matlab environment, and afterward was realized by embedding the soft computer program into a DSPIC as the controlling system. Dumanay [32] realized a remote control laboratory for automatic control course in Electrical-Electronics and other engineering departments. PID, Fuzzy-Logic and Sliding Mode controllers have been applied for DC motor speed successfully. Özdemir [33] used fuzzy logic control of direct current motor in light metro traction systems. Erkan [34] and Koyuncu [35] used fuzzy logic to control direct current motors. Vardar [36] managed direct current motor speed control using fuzzy logic. Bulut [37] managed PC based PI-type control of DC motor aided genetic algorithms. Dalc1 [38] improved the performance of the permanent magnet direct current motor using proportional and integral controller which parameters are adjusted by fuzzy logic at the starting time. Koca [39] has set up a robust speed controller to control a brushless motor of a rear driven electric vehicle, using sliding mode control and fuzzy logic. Özbay [40] applied fuzzy logic to control a separate excitation type DC motor. Samyeli [41] compared PID and Fuzzy logic control of a permanent magnet DC motor.

\subsection{Travelling (Linear) Type Electric Machines}

Aktaş [42] applied fuzzy logic control to a linear AC motor. Hasırc1 [43] used neuro-fuzzy techniques to control a DC linear motor. Özkop [44] has realized a Fuzzy Logic Control for the Single Sided Linear Induction Motor.

\subsection{Special-Purpose Electric Machines}

Gürleyük [45] has worked on analysis of dynamic behaviour and fuzzy logic control of the linear permanent magnet tubular step motor. Dağdelen [46] modeled a position control of a step motor using fuzzy logic. Subaşı [47], Genç [48] and Korkmaz 
[49] used fuzzy logic to control brushless DC motor. Kılınç [50] designed and implemented a fuzzy logic based drive system for current, position and speed control of a brushless DC motor. Gençer [51] used neuro-fuzzy controller to control brushless DC motor of speed and position. Aydoğdu [52] simulated and managed sensorless speed control of brushless DC motors by means of genetic based fuzzy controller. In accomplishing optimization of developed control system, a multi-objective performance index has been defined and it has been used as objective function to be minimized in genetic algorithm.

Bay [53] modeled and controlled of a switched reluctance motor based on fuzzy logic. Akçayol [54] managed neuro-fuzzy control of a switching reluctance motor in a wide range of speed. Sezen [55] used a new fuzzy logic algorithm to manage finite element method (FEM) analyzed high power switched reluctance motor speed control. Duran [56] developed an intelligent controlled industrial type washing machine using a Switched Reluctance Motor. Derdiyok [57] used fuzzy logic and sliding mode control to reduce torque ripple of a SRM.

Ulusoy [58] compared PID tuning and fuzzy control applications using a microcomputer controlled DC servo system. Okuyucu [59] formed a fuzzy controlled DC motor training set. Küçükdemiral [60] designed neural-genetic based optimal fuzzy controller and application to DC servomotor. Altınörs [61] presented a new control scheme is presented for the robust speed control of servo motors. The proposed control method is based on Type-2 Fuzzy Logic and Sliding Mode Control (SMC) techniques. Alkan [62] realized a high speed fuzzy controller for adaptive control of a servo motor. Küçüksille [63] realized speed control of a servo motor by the fuzzy logic. Akar [64] compared conventional and fuzzy logic control of a servo motor. Büyüksavc1 [65] managed PD, fuzzy logic and sliding mode control of an electro-hydraulic servo system. Haydim [66] realized position control of an electro hydraulic servo system using fuzzy logic and PD control method. Servo-valve torque motor is used in the study.

Hartavi [67] presented the Fuzzy Supervisory Control (FSC) and bias current optimization algorithm developed for a Rotor-Active Magnetic Bearing (Rotor-AMB) system. Kesler [68] implemented a fuzzy logic based speed controller for the slip-ring induction motor using TMS320F2812 DSP. Bekiroğlu [69] implemented speed and position control of a travelling wave ultrasonic motor by using fuzzy logic controller. Hüner [70] fuzzy controlled a travelling wave ultrasonic motor.

\section{CONCLUSIONS}

This study is aimed to reveal studies on fuzzy logic in Turkish Universities. Fuzzy logic studies are given in an organized way.

Refereed theses are searched on the website of Turkish Council of Higher Education. This work is a small part of another work that all fuzzy logic studies at all Turkish universities are searched and then classified. All data belong to the database formed up to the 2010. Even though some studies may be not yet registered to the database; it is believed that number is small.

There are 936 studies on fuzzy logic in Turkish Universities. Among them, 62 studies are on fuzzy logic control of electrical machines. On the other hand, investigated studies are completed in a 20 year time interval. 
40 studies are MSc theses and 22 studies are $\mathrm{PhD}$ theses. Number of $\mathrm{PhD}$ theses are approximately is half of that of MSc theses. But, it is encouraging because it is more than expected. Normally, number of PhD theses is less than quarter of MSc theses. Only 4 studies are written in English.

There are 95 state and 34 private universities and 5 military institutions in Turkey. Investigated studies are done at 21 state universities. More than half of studies are done at 5 universities (Y1ldiz Technical University, Karadeniz Technical University, Gazi University, Firat University, and Marmara University). Studies have begun at 1991. It is rather late when the history of fuzzy logic is concerned. But, during last decade, studies are doubled according to the previous decade.

As a topic, there is no study on fixed type electrical machines. Also, there are a few studies on some topics (generators, linear motors, step motors and slip-ring motor). It is recommended for researchers to study these topics.

As a control method, there is only one study which used Type II fuzzy logic. There should be more study using this method. Hierarchical fuzzy control and adaptive fuzzy control methods can be optimized by using genetic and neural-network algorithms. Classical fuzzy logic is used together with different algorithms to optimize the control in some studies (neural network and genetic algorithm). There are more algorithms in literature. They can be used and compared with previous ones, especially evolutionary algorithms.

Moreover, effect of using different membership functions can be investigated. Lastly, in most study, fuzzy logic is used to control speed instead position and torque. It is recommended to use fuzzy logic to control also position and torque.

\section{ACKNOWLEDGMENT}

The author wishes to thank Ass. Prof. Dr. Fevzi KENTLI for his valuable comments and discussions through this work.

\section{REFERENCES}

1. L.A. Zadeh, Fuzzy Sets, Information and Control 8, 338-353, 1965

2. L.A. Zadeh, Outline of a new approach to the analysis of complex systems and decision processes, IEEE Trans. Systems, Man and Cybernetics 3, 28-44, 1973

3. E.H. Mamdani, Applications of fuzzy algorithms for simple dynamic plant, Proc. IEE 121(12), $1585-1588,1974$

4. L.P. Holmblad and J.J. Ostergaard, Control of a cement kiln by fuzzy logic, In M.M. Gupta and E. Sanchez, editors, Fuzzy Information and Decision Processes, 389-399, North-Holland, 1982

5. L. Reznik, Fuzzy controllers, Newnes, Oxford, 1997

6. S.A. Nasar, Schaum's Outline of Electric Machines \& Electromechanics, McGrawHill, 1997

7. I. Boldea and S.A. Nasar, Linear Motion Electric Machines, John Wiley \& Sons, Canada, 1976

8. G. Rizzoni, Principles and applications of Electrical Engineering, McGraw-Hill, 1997 
9. M. Cirstea, A. Dinu, M. McCormick, and J.G. Khor, Neural and Fuzzy Logic Control of Drives and Power Systems, Newnes, 2002

10. Y. Song and A.T. Johns, Applications of Fuzzy Logic in Power Systems: Part 1, IEE Power Engineering Journal, 11(5), 219-222, 1997

11. Y. Song and A.T. Johns, Applications of Fuzzy Logic in Power Systems: Part 2, IEE Power Engineering Journal, 12(4), 185-190, 1998

12. S. Kavruk, Türbin-jeneratör sisteminin neuro-fuzzy denetleyici ile kontrolü, İnönü University, MSc Thesis, 2005

13. Ö.G. Kinal1, Regeneratif enerji sistemlerinde generatörlerin modellenmesi ve bulanık mantık ile kontrolü, Kırıkkale University, MSc Thesis, 2007

14. Y. Oğuz, Senkron jeneratörlerin uyartım devresinin bulanık mantıkla kontrolü, Marmara University, MSc Thesis, 2000

15. M.K. Eker, Senkron generatör uyarma devresinin bulanık mantıkla denetimi, Karadeniz Technical University, $\mathrm{PhD}$ Thesis, 2005

16. M. Caner, Hiyerarşik fuzzy yöntemiyle senkron generatörlerde uyartım kontrolü, Y1ldız Technical University, PhD Thesis, 2006

17. A. Çaşkurlu, Üç fazlı asenkron makinanın bulanık mantık kullanarak kontrolu, Karadeniz Technical University, MSc Thesis, 1996

18. A.F. Uygur, Bir asenkron motor hiz denetim sisteminin neuro-fuzzy yöntemlerle gerçekleştirilmesi, Kahramanmaraş Sütçü İmam University, MSc Thesis, 2002

19. M. Demirtaş, Alan yönlendirmeli asenkron motorun bulanık kayan kip ve genetik kayan kip konum kontrolü, Y1ld1z Technical University, PhD Thesis, 2002

20. R. Arınç, Bulanık mantık yöntemiyle asenkron motor hız kontrolü ve simülasyonu, Marmara University, MSc Thesis. 2003

21. B. Dandıl, Sinirsel bulanık denetleyicilerle asenkron motorun dayanıkl hız denetimi, Frrat University, PhD Thesis, 2004

22. C. Bal, Asenkron motorun kayma kipli ve sinirsel bulanı gözlemleyicilerle algılayıcısız hız denetimi, Firat University, PhD Thesis, 2007

23. C. Yıldız, Genetik algoritma destekli bulanık denetim kullanarak vektör esasl asenkron motor kontrolü, Kahramanmaraş Sütçü İmam University, MSc Thesis, 2008

24. Z. Kıvanç, Adaptive fuzzy controller of a thermal system and an induction motor using existing PLCs, Boğaziçi University, MSc Thesis, 1999

25. B. Gümüş, Sürekli mıknatıslı senkron motorun bulanık mantık gözlemleyicisi kullanarak vektör kontrölü, Firat University, PhD Thesis, 2004

26. O. Üstün, Sürekli mıknatıslı bir senkron motor hızının bulanık sinirsel ve kayma kipli denetleyicilerle dönüşümlü denetimi, Gazi University, PhD Thesis, 2004

27. F. Kaytez, Klasik PID ve bulanık mantık kontrolör ile senkron elektrik makine kontrolü, Gazi University, MSc Thesis, 2005

28. A. Teker, Sürekli mıknatıslı senkron motorun bulanık mantık ile hız kontrolü, Kocaeli University, MSc Thesis, 2008

29. E. K1lıç, Senkron motor güç katsayısının bulanık mantık ile denetimi, Karadeniz Technical University, MSc Thesis, 1996

30. M.M. Faris, Bulanık mantık uygulamasıyla DC motorun hız kontrolü, Gazi University, MSc Thesis, 2008

31. N. Baysal, Adaptif ăg yapısına dayalı bulanık çıkarım sisteminin (ANFIS) sayısal işaret işlemci ile gerçekleştirilmesi ve uygulaması, İnönü University, MSc Thesis, 2009 
32. A.B. Dumanay, PID, bulanık mantık ve kayan kip kontrol yöntemleri ile internet üzerinden dc motor hız kontrolü, Balıkesir University, MSc Thesis, 2009

33. E. Özdemir, Doğru akım motorunun bulanı mantık ile denetimi ve hafif metro tahrik sisteminde kullanilabilirliği, Kocaeli University, PhD Thesis, 1997

34. K. Erkan, Bulanık mantık ile doğru akım motor kontrolünün incelenmesi, Yı1dız Technical University, MSc Thesis, 1999

35. M. Koyuncu, Elektrik makinalarının kontrolunda bulanık mantık uygulaması, Marmara University, MSc Thesis, 1997

36. K. Vardar, Doğru akım motor hızının bulanık mantık ile kontrolü, Dumlupınar University, MSc Thesis, 2004

37. M. Bulut, Doğru akım motorunun genetik algoritmalar yardımıyla bilgisayar temelli PI-tip bulanık mantık kontrolü, Y1ldı Technical University, PhD Thesis, 2001

38. K.B. Dalc1, Parametreleri bulanık mantık kullanılarak ayarlanan oran ve integral kontrolörü ile daimi mıtnatıslı doğru akım motorunun kalkıs anındaki performansının arttırllması, Y1ldız Technical University, PhD Thesis, 2000

39. G.Ö. Koca, Kayma kipli kontrol ve bulanık mantık kullanarak elektrikli araçların hiz kontrolü, Firat University, MSc Thesis, 2005

40. E. Özbay, Bulanık mantık ile motor kontrolünün incelenmesi, Y1ldız Technical University, MSc Thesis, 1995

41. C. Samyeli, Klasik kontrol yöntemleri ve bulanık denetimin bir PMDC motorda denenerek sonuçların karşılaştırılması, Karadeniz Technical University, MSc Thesis, 1998

42. M. Aktaş, Doğrusal hareketli asenkron motorun bulanık mantık ile kontrolü, Karadeniz Technical University, MSc Thesis, 1998

43. U. Hasırcı, Yapay sinir ağları ve bulanık mantıkla DC lineer motor kontrolü, Gebze Institute of Technology, MSc Thesis, 2005

44. E. Özkop, Doğrusal hareketli asenkron motorun bulanık mantıkla kontrolü, Karadeniz Technical University, MSc Thesis, 2006

45. S.S. Gürleyük, Doğrusal hareketli tüpsel yapılı sürekli mıknatıslı adım motorunun dinamik davranışının incelenmesi ve bulanık mantık temelli denetimi, Karadeniz Technical University, PhD Thesis, 1997

46. U. Dağdelen, Bulanık mantık ile adım motor kontrolü, Erciyes University, MSc Thesis, 1996

47. Y. Subaş1, Fuzzy control of brushless DC motors, Middle East Technical University, MSc Thesis, 1998

48. N. Genç, Fırçasız doğru akım (DA) motorlarının bulanık mantık yöntemi ile kontrolü, Yüzüncü Y1l University, MSc Thesis, 2002

49. K. Korkmaz, Fırçasız D.C. motorların bulanık mantık yöntemi kullanılarak ADSP2101 (digital signal processor) ile kontrolü, Marmara University, PhD Thesis, 1999

50. D. Kılınç, Design and implementation of a fuzzy logic based drive system for current, position and speed control of a brushless DC motor, Çukurova University, MSc Thesis, 2002

51. Ç. Gençer, Fırçasız doğru akım motor hız ve konumunun bulanık sinirsel denetleyici ile denetimi, Gazi University, $\mathrm{PhD}$ Thesis, 2005

52. Ö. Aydoğdu, Fırçasız doğru akım motorlarının genetik tabanlı bulanık denetleyici ile sensörsüz kontrolü, Selçuk University, PhD Thesis, 2006 
53. Ö.F. Bay, Anahtarlamalı relüktans motorun bulanık mantık tabanlı modellenmesi ve kontrolu, Erciyes University, PhD Thesis, 1996

54. M.A. Akcayol, Bir anahtarlamalı relüktans motorun sinirsel-bulanık denetimi, Gazi University, PhD Thesis, 2001

55. S. Sezen, Sonlu elemanlar yöntemi (SEY) ile analizi yapılmış yüksek güçlü anahtarlamalı relüktans motorun yeni bir bulanık mantık algoritması kullanılarak hız denetimi, Kocaeli University, MSc Thesis, 2006

56. F. Duran, Endüstriyel çamaşır makinelerinde anahtarlamalı relüktans motoru kullanımı ve sistemin zeki denetimi, Gazi University, $\mathrm{PhD}$ Thesis, 2008

57. A. Derdiyok, Anahtarlamall relüktans motorun doyma modeline ortak endüktans etkilerinin inmcelenmesi ve bulanik ve kayan kipli denetleyicilerle moment dalgalanmasinın azaltılması, Y1ldı Technical University, PhD Thesis, 1997

58. H. Ulusoy, A Comparison of pid tuning and fuzzy control applications using a microcomputer controlled DC servo system, Bosphorus University, MSc Thesis, 1991

59. S. Okuyucu, Bulanık kontrollü DC motor eğitim setinin oluşturulması, Marmara University, MSc Thesis, 2001

60. İ.B. Küçükdemiral, Nöral-genetik tabanlı optimal bulanık kontrolörün gerçeklenmesi ve DC servomotora uygulanması, Yıldız Technical University, PhD Thesis, 2002

61. A. Altınörs, Tip-II bulanık mantık ve kayma kipli kontrol yöntemleri ile servo sistemlerin dayanıklı kontrolü, Firat University, PhD Thesis, 2007

62. Ş. Alkan, Yüksek hızl fuzzy lojik kontrolcü kullanarak bir servo motorun adaptif kontrolü, Y1ldız Technical University, MSc Thesis, 1994

63. E.U. Küçüksille, Servo motorların bulanık mantık yöntemi ile kontrolü, Süleyman Demirel University, MSc Thesis, 2002

64. M. Akar, Bulanık mantık yöntemiyle bir servo motorun kontrolü ve geleneksel yöntemlerle karşılaştırılması, Marmara University, MSc Thesis, 2005

65. M. Büyüksavc1, Elektrohidrolik sir servo sistemin PD, bulanık mantık ve kayan resimli konum kontrolü, İstanbul Technical University, MSc Thesis, 1999

66. M. Haydim, Elektro hidrolik servo sistemlerde bulanık mantık yaklaşımıyla konum kontrolü, Selçuk University, MSc Thesis, 2006

67. A.E. Hartavi, Rotor-AMY sisteminin bulanık denetleyici ile kontrolü ve denge akımının eniyileştirilmesi, İstanbul Technical University, PhD Thesis, 2005

68. S. Kesler, Bilezikli asenkron makinaların bilezikleri üzerinden bulanık mantık tabanl hız denetiminin TMS320F2812 DSP ile gerçekleştirilmesi, Karadeniz Technical University, PhD Thesis, 2006

69. E. Bekiroğlu, Yürüyen dalga ultrasonik motorun hiz ve konum denetiminin bulanık mantık denetleyici kullanarak gerçekleştirilmesi, Gazi University, PhD Thesis, 2002

70. E. Hüner, Yürüyen dalga tipli ultrasonik motorun bulanık mantık ile kontrolü, Gebze Institute of Technology, MSc Thesis, 2005

71. N. Kepez, Elektrik makinaları kontrolünde bulanık mantı̆̆ın uygulanması, İstanbul Technical University, MSc Thesis, 1995

72. H. Ayluçtarhan, Elektrik motorlarının bulanık mantıkla denetlenmesi, İstanbul University, MSc Thesis, 2003

73. S. Tuncer, Değişken hızlı sürücü sistemleri için fuzzy denetleyicili yeni bir algoritmanın geliştirilmesi ve uygulaması, Furat University, MSc Thesis, 1999 